MARINE MAMMAL SCIENCE, 30(1): 242-258 (January 2014)

(C) 2013 by the Society for Marine Mammalogy

DOI: $10.1111 / \mathrm{mms} .12034$

\title{
Prey preferences of sympatric fin (Balaenoptera physalus) and humpback (Megaptera novaeangliae) whales revealed by stable isotope mixing models
}

Conor Ryan, ${ }^{1}$ Marine and Freshwater Research Centre, Department of Life Science, Galway-Mayo Institute of Technology, Galway, Ireland; Simon D. BerRow, Marine Biodiversity Research Group, Department of Life Science, Galway-Mayo Institute of Technology, Galway, Ireland and Irish Whale and Dolphin Group, Merchant's Quay, Kilrush, Co. Clare, Ireland; Brendan McHugh and Ciarán O’Donnell, Marine Institute, Rinville, Oranmore, Co., Galway, Ireland; CuIve N. Trueman, Ocean and Earth Science, University of Southampton, National Oceanography Centre, Southampton European Way, Southampton, SO14 3ZH, United Kingdom; IAN O'Connor, Marine Biodiversity Research Group, Department of Life Science, Galway-Mayo Institute of Technology, Galway, Ireland.

\begin{abstract}
Over-exploitation of top predators and fish stocks has altered ecosystems towards less productive systems with fewer trophic levels. In the Celtic Sea (CS), discards and bycatch levels have prompted concern about some fisheries, while fin and humpback whales are recovering from centuries of over-exploitation. A lack of empirical evidence on the preferred diet of some predators such as whales in the CS has hindered the implementation of effective conservation measures using an ecosystem-based approach to fisheries management. Using a Bayesian framework (SIAR), stable carbon $\left(\delta^{13} \mathrm{C}\right)$ and nitrogen $\left(\delta^{15} \mathrm{~N}\right)$ isotope mixing models were used to assign proportionate diet solutions to fin and humpback whales (skin biopsies) and putative prey items: herring (Clupea harengus), sprat (Sprattus sprattus), and krill (Meganyctiphanes norvegica and Nyctiphanes couchii) in the CS. Krill was the single most important prey item in the diet of fin whales, but one of the least important for humpback whales (albeit based on a small sample of humpback whale samples). Age 0 sprat and herring comprised a large proportion of the diet of both species, followed by older sprat (age 1-2) and older herring (age 2-4). An ecosystem based approach to fisheries management will be required in the CS if we seek effective conservation of both fin and humpback whales, and sustainable fisheries.
\end{abstract}

Key words: diet, SIAR, Bayesian mixing model, biopsy, Balaenopteridae.

Ecosystem based management should strive to secure ecosystem functioning, thereby increasing the value of an ecosystem for subsequent generations. For the

\footnotetext{
${ }^{1}$ Corresponding author (e-mail: miolmor@gmail.com).
} 
majority of cases, management of fisheries aims to maximize the yield of target species, which is rarely achieved without detrimental effects to the ecosystem (Pauly et al. 1998, Pinnegar et al. 2002, Pikitch et al. 2004). Recently it has been argued by nations with a whaling interest, that culling of marine mammals could be used as a means to increase fisheries yield given that they consume large quantities of fish. However this approach is inherently flawed as fisheries do not exert a comparable regulatory force on fish biomass as do top predators (e.g., Gerber et al. 2009). Furthermore, culling programs rarely achieve measurable objectives, rendering their effectiveness inestimable (Bowen and Lidgard, 2012). The removal of top predators results in different outcomes for ecosystems that function under predominantly topdown or bottom-up controls (Trites et al. 2006). The anthropogenic alterations of marine ecosystems are such that fish productivity has been reduced, as indicated by prolific lowering of trophic systems, forcing predators to consume food lower down on the food web (Pinnegar et al. 2002) or of suboptimal quality (Österblom et al. 2008). According to life history theory, for top predators such as marine mammals that require energy-rich prey in high densities, food shortages will lead to reduced body condition and hence reduced reproductive output (Stearns 1976, Le Boeuf 1994, Greene and Pershing 2004). Thus predation pressure exerted by natural top predators is self-regulating within the ecosystem, whereas predation from fisheries is not. Fisheries management aims to apply similar checks to fisheries pressures, with mixed results (Pauly et al. 2002). Lowered trophic systems, implicit with reduced availability of preferred prey, has exacerbated population declines in already threatened predators such as seabirds (Becker and Beissinger 2006, Österblom et al. 2008). An understanding of the ecosystem roles and life histories of predators such as cetaceans is key in developing effective conservation measures in ecosystems based management (Hooker and Gerber 2004).

Direct observation of predation and food consumption of marine predators such as fin (Balaenoptera physalus) and humpback whales (Megaptera novaeangliae) is challenging. Conventional foraging studies (e.g., stomach content analysis and direct observations) are subject to biases and are difficult to carry out under ecologically relevant timescales, particularly for wide ranging species such as cetaceans (Pierce et al. 2007). Stable carbon $\left(\delta^{13} \mathrm{C}\right)$ and nitrogen $\left(\delta^{15} \mathrm{~N}\right)^{2}$ isotopes are tracers of nutrients and energy through food webs in that they reflect the environment and prey from which tissues of predators are synthesized (DeNiro and Epstein 1978, 1981). Stable isotope analysis has become a frequently used means for exploring diet, foraging strategies, and migration in animal ecology (Hobson 1999, Newsome et al. 2010). However accurate estimates of: isotope values, uncertainty in predator and prey tissue isotopes, tissue-to-source fractionation of stable isotopes, as well as turnover rate of the tissues used must be known before accurate modeling and interpretation of results can be carried out (Focken and Becker 1998, Phillips and Gregg 2001, Martínez del Rio et al. 2009). Stable isotope values of tissues such as skin, which for cetaceans can be sampled remotely by biopsy darting, reflect those of dietary sources over a time period that depends on tissue turnover rate. Turnover rates for skin have been reported to be between seven days and one month for humpback whales, although this has never been tested, considering the logistical challenge of controlled experiments on large cetaceans (Todd et al. 1997, Caut et al. 2011, Witteveen et al. 2011). Turnover

\footnotetext{
${ }^{2}$ Isotope ratios are presented in delta notation as parts per thousand differences from international standards according to the following equation: $\delta^{Y} X=\left[\left(R_{\text {sample }} / R_{\text {standard }}\right)-1\right] \times 10^{-3}$, where $R$ denotes the heavier:lighter isotope ratio and $Y$ is the atomic mass of the stable isotope $X\left(\delta^{13} \mathrm{C}\right.$ or $\left.\delta^{15} \mathrm{~N}\right)$.
} 
rate for skin collagen in other mammals such as rats, beluga whales (Delphinapterus leucas) and some dolphin species is 70-75 d (Hicks et al. 1985, St. Aubin et al. 1990, Rucklidge et al. 1992).

Using mass balance models (mixing models), it is possible to estimate proportionate contributions of distinct prey (sources) in the ultimate diet of consumers (mixture) using stable isotope values (Peterson and Fry 1987, Gearing et al. 1991, Phillips and Gregg 2003). Simple linear mixing models can be used to resolve diet solutions by Euclidean distances between $\delta^{13} \mathrm{C}$ and $\delta^{15} \mathrm{~N}$ in biplot space but these models are constrained by the number of isotopes $(n)$ used, limiting the number of sources that can be solved to $n+1$. Phillips (2001) established a theoretical framework for more complex models that allow for a greater number of sources to be considered, known as IsoSource (Phillips and Gregg 2003). However, as the number of sources used in a mixture increases, so too does the uncertainty in the source combinations. To counter this issue, a Bayesian framework (MixSIR) was adopted which permitted any number of sources to be considered, providing probabilistic distributions of percentage source contributions (Moore and Semmens 2008). Similarly, Stable Isotope Analysis in R, or SIAR models explicitly recognize uncertainty from a number of sources, but include diet-tissue fractionation and incorporate them into model parameter estimates (Parnell et al. 2008, R Development Core Team 2011). This approach, has allowed robust dietary solutions to be derived in several vertebrate species, such as humpback whales using skin biopsies as the consumer mixture and putative prey items as sources (e.g., Witteveen et al. 2011).

Spatial and temporal variation in isotopic baseline of the marine environment (i.e., in phytoplankton tissues) is considerable, ultimately driven by sea temperature, water chemistry, day length, plankton species composition, plankton biomass and carbon and nitrogen uptake regime (Goericke and Fry 1994, Hofmann et al. 2000, Jennings and Warr 2003, Tagliabue and Bopp 2008). Prey should be sampled at a scale (both spatial and temporal) relevant to the predator and tissue examined, such that confounding effects of both spatial and temporal variation can be minimized. However, the potential bias associated with source turnover for contributions depend on the adequacy of the selected sources (i.e., putative prey), which should be based on empirical evidence (Phillips et al. 2005, Ward et al. 2011).

Euphausiidae (hereafter referred to as krill) are key species in marine food webs, supporting biomass of pelagic predators including baleen whales (Verity et al. 2002). The most abundant species found in the Celtic Sea (CS) are Meganyctiphanes norvegica and Nyctiphanes couchii, whose distributions are generally confined to continental slopes and shelf waters respectively (Lindley 1982). In the North Atlantic, stomach content analysis carried out at whaling stations (Brodie et al. 1978, Fairley 1981), supported by modeling spatial associations, confirm that some fin whales feed chiefly on M. norvegica, capelin (Mallotus villotus) and herring (Clupea harengus) (Piatt et al. 1989, Skern-Mauritzen et al. 2011). In the Northeast Atlantic (NEA), fin whales are definitive hosts of Bolbosoma balaenae, an acanthocephalan parasite for which N. couchii is an intermediate host. This host-parasite relationship indicates that fin whales probably also feed on N. couchii in the NEA (Gregori et al. 2012). The diet of humpback whales in the NEA is poorly studied, although they are known to be generalists feeding on amphipods, capelin, clupeids and krill (Piatt et al. 1989, Skern-Mauritzen et al. 2011). They have been observed foraging in association with fin whales in the CS (Whooley et al. 2011).

In the CS, fin and humpback whales associate with a seasonal inshore movement of spawning herring (Clupea harengus) (Whooley et al. 2011). These herring comprise 
two stocks targeted by a single fishery. Historically, these stocks have collapsed possibly as a result of a combination of over-exploitation and environmental factors (Lynch et al. 2011, Harma et al. 2012). Sprat (Sprattus sprattus) is a major bycatch component of other fisheries in the CS (e.g., for groundfish and herring), but there is also a targeted fishery that is not currently managed or assessed by the Intergovernmental Counsel for the Exploration of the Seas (ICES) for which there is an open quota (Enever $e$ t al. 2007). Moreover, sprat are recognized as an important prey for several predators in the CS ecosystem (Trenkel et al. 2005, Chivers et al. 2012).

In order to effectively conserve fin and humpback whales in the CS, their basic requirements and roles in the ecosystem must be identified, so that threats to their habitat, survival, and population growth can be identified and alleviated. Towards achieving this goal, the present study aims to estimate relative contributions of krill and clupeid fish in the diet of fin whales and humpback whales that occur sympatrically in the Celtic Sea (CS) using stable isotope Bayesian mixing models. It is hoped that this information may aid the development of ecosystems based approach to fisheries management.

\section{METHODS}

\section{Sampling}

The study area comprised the CS and coastal waters to the south of Ireland (Fig. 1). A literature review and photographic evidence of surface active feeding were used to identify a priori the most likely prey (sources) contributing to the diet of both fin and humpback whales (mixture) in the CS. Herring (C. harengus) and sprat (S. sprattus) were caught by pelagic trawl during dedicated herring fisheries surveys and plankton samples were collected in a ring net $(1 \mathrm{~m}$ diameter, $360 \mu \mathrm{m}$ mesh) using vertical tows. Plankton samples were collected during February 2010 and fish samples were collected on 18 October 2010 from the RV Celtic Explorer. Skin biopsies were collected from whales between November 2009 and July 2011. Species identification of zooplankton was carried out under the microscope.

Skin biopsies were collected from fin and humpback whales from small boats (5$12 \mathrm{~m}$ ) using modified bolts (CETA-DART) fired from a crossbow (150 lb drawstrength). Steel sampling tips (40 mm depth; Specials Engineering, Galway, Ireland) were fitted to the top of the bolts, which have a compressed foam stop-collar to limit penetration, facilitate rebound and provide buoyancy to the bolt to aid retrieval without the need for a tether. Tips were scrubbed in soapy water, sterilized, solventrinsed, and foil-wrapped prior to use. Samples were removed from the tips using solvent-rinsed forceps, wrapped in aluminum foil, and transported at $-20^{\circ} \mathrm{C}$ to the laboratory whereupon they were stored in glass vials at $-80^{\circ} \mathrm{C}$ until analysis. Photo identification of individual whales was used to avoid duplicate sampling in the field (see Whooley et al. 2011).

\section{Tissue Preparation}

Briefly, lipids were extracted only from whale skin samples, but carbon and nitrogen isotope ratios were determined separately to circumvent undesired effects on $\delta^{15} \mathrm{~N}$. Zooplankton were acidified without further treatment but were corrected for the presence of lipids when deemed appropriate, based on C:N ratios. Finally, fish 


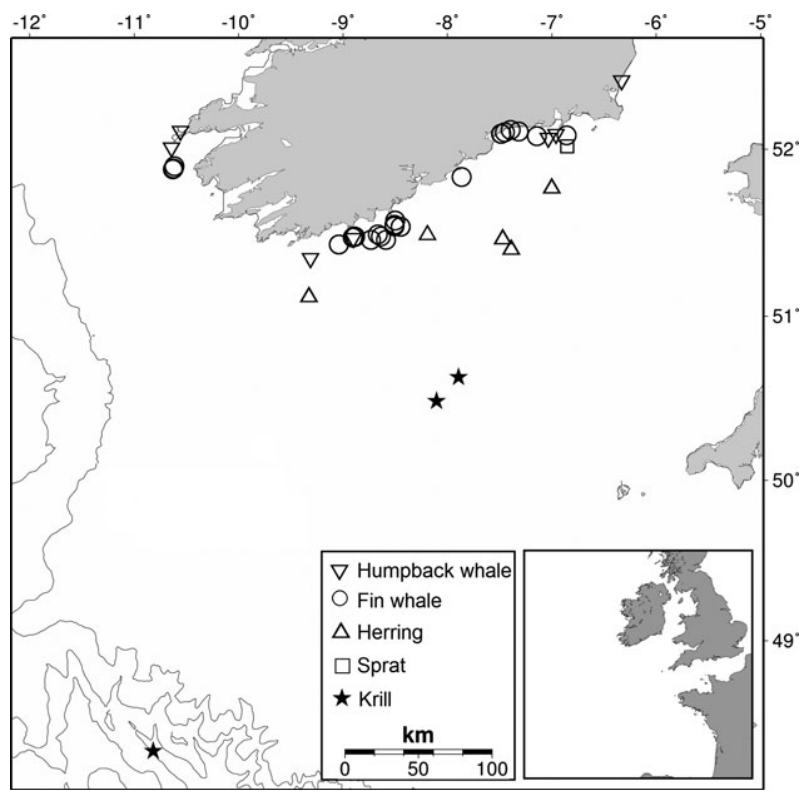

Figure 1. Map of study site showing sampling locations.

muscle samples were analyzed without treatment, but were also lipid-corrected when appropriate based on $\mathrm{C}: \mathrm{N}$ ratios. As such, all known sources of bias arising from tissue treatment and the presence of both lipids and carbonates were accounted for, with the exception perhaps of $\delta^{15} \mathrm{~N}$ in zooplankton which may decrease by up to $0.32 \%$ following acidification (Jacob et al. 2005). Although several studies have shown that acidification has a negligible effect on $\delta^{15} \mathrm{~N}$ as long as lipids are not extracted (Sotiropoulos et al. 2004, Søreide et al. 2006, Sweeting et al. 2006) and provided that the acidified samples are not washed with water (Jacob et al. 2005).

From above the lateral line, white muscle samples from each fish were excised, homogenized and $0.5 \mathrm{~g}$ aliquots were freeze-dried for $24 \mathrm{~h}$. Whole individual zooplankton specimens were also freeze-dried for $24 \mathrm{~h}$ followed by removal of carbonates by soaking in a $2 \mathrm{M} \mathrm{HCl}$ for $5 \mathrm{~min}$, or until effervescence had ceased (Søreide et al. 2006). After drying in a fume hood, individual zooplankton samples were homogenized and ground to a fine powder using a pestle and mortar. Whale skin samples were duplicated and diced finely using solvent-washed scalpels on clean glass slides. Entire longitudinal profiles of the skin biopsies to a depth of $c a .10 \mathrm{~mm}$ were analyzed. Lipids were extracted for $24 \mathrm{~h}$ ( $6 \mathrm{~h}$ refluxing, $18 \mathrm{~h}$ soaking) in Soxhlet washed glass microfibre thimbles with $150 \mathrm{~mL}$ of 1:1 $n$-hexane and acetone (Ryan et al. 2013). Both lipid-extracted and bulk skin samples were homogenized using a mortar and pestle. $C a .1 .5 \mathrm{~g}$ of prepared tissues were weighed accurately into tin cups.

Ageing

The age of sprat and herring was considered an important factor given that stable isotopic composition is likely to change with size and thus age in pelagic fishes (e.g., Overman and Parrish 2001, Jennings et al. 2002). Furthermore, selective foraging for 
certain prey age-classes by predators such as baleen whales is possible (Griffiths 1980). Standard length was recorded for each fish in order to estimate age. Age for herring and sprat was determined using length-at-age regression models that are derived during routine pelagic trawl surveys for stock assessment (Saunders et al. 2010).

\section{Stable Isotope Analysis}

Carbon and nitrogen isotope composition of whale skin was determined using continuous flow elemental analysis isotope ratio mass spectrometry (CF-EA-IRMS) at the University of Southampton using a EuroVector EA 3000 (EA) combined with a PDZ Europa Scientific 20-20 (IRMS). Isotope ratios are presented in delta notation as parts per thousand differences from an internal standard (ACROS L-Glutamic Acid) according to the following equation: $\delta^{Y} X=\left[\left(R_{\text {sample }} / R_{\text {standard }}\right)-1\right] \times 10^{-3}$, where $R$ denotes the heavier:lighter isotope ratio and $Y$ is the atomic mass of the stable isotope $X\left(\delta^{13} \mathrm{C}\right.$ or $\left.\delta^{15} \mathrm{~N}\right)$. Internal standards calibrated with International Atomic Energy Agency IAEA (Vienna, Austria), i.e., Vienna Pee Dee Belemnite (for C), atmospheric $\mathrm{N}_{2}$ (for $\mathrm{N}$ ), were routinely analyzed between samples in order to determine instrument precision. Based on the two standard deviations of these standards, the analytical precision of two runs at separate laboratories was similar $0.4 \%$ and $0.2 \%$ for nitrogen, and $0.2 \%$ and $0.1 \%$ for carbon for Southampton and University of California Davis respectively. Prey items (fish muscle and homogenized krill) were analyzed at UC Davis by CF-EA-IRMS using a PDZ Europa ANCA-GSL (EA) combined with a PDZ Europa 20-20 (IRMS). The analytical precision at Southampton, calculated as the standard deviation of routinely measured bovine liver and glutamic acid standards, was $0.40 \%$ for nitrogen, and $0.20 \%$ for carbon. At the UC Davis laboratory, this was $0.15 \%$ and $0.06 \%$ for nitrogen and carbon, respectively.

\section{Correction of $\delta^{13} \mathrm{C}$}

In exoskeletons of crustaceans such as krill, carbonates $\left(\mathrm{CaCO}_{3}\right)$ are derived from isotopically heavy $\mathrm{HCO}_{3}{ }^{-}$ions from the environment, and are thus a nondietary fraction and must also be removed as their enriched ${ }^{13} \mathrm{C}$ affects whole-body $\delta^{13} \mathrm{C}$ values (Søreide et al. 2006). Lipids are depleted in ${ }^{13} \mathrm{C}$, thus altering the $\delta^{13} \mathrm{C}$ values of tissues. The elemental carbon to nitrogen ratio $(\mathrm{C}: \mathrm{N})$ is a useful proxy for lipid content (McConnaughey and McRoy 1979) and was used to assess lipid effects on isotopic values in light of those previously published species- and tissue-specific values for lean tissue. Lipid-free C:N values for whole zooplankton (range) are 3.30-4.03 for marine zooplankton (Kiljunen et al. 2006, Søreide et al. 2006), ( \pm SD) $3.6 \pm 0.1$ for M. norvegica (Bentaleb et al. 2011) and $3.3 \pm 0.1$ for white muscle in sprat and herring of (Kiljunen et al. 2006, Caut et al. 2011). These were used as a threshold lipidfree and/or carbonate-free values for each species, which if exceeded indicated that all $\delta^{13} \mathrm{C}$ values for that species should be corrected arithmetically (i.e., lipid-normalized) to correct for the presence of isotopically lighter lipid (Table 1). The normalization model used to estimate lipid-free $\delta^{13} \mathrm{C}$ values is a nonlinear equation from Kiljunen et al. (2006) requiring the C:N ratio and the isotopic discrimination factor between lipid and protein $(D=7.018 \pm 0.263)$ of the sample, and a constant $(I=0.048 \pm 0.013)$. After carbonate extraction of krill samples, the sample C:N threshold values were also used to confirm that carbonates had been fully extracted (Søreide et al. 2006). Normalization for the effects of lipid on $\delta^{13} \mathrm{C}$ values in fin and 
Table 1. Mean $\delta^{13} \mathrm{C}, \delta^{15} \mathrm{~N}$ and C:N values (standard deviation in parenthesis) for consumer and source values used in the mixing model. Lipid extracted and lipid normalized values are denoted by $*$ and $* *$, respectively. Criteria for normalization of $\delta^{13} \mathrm{C}$ for lipid content was $\mathrm{C}: \mathrm{N}>3.4$ for sprat or herring, and C:N > 4.0 for krill (Kiljunen et al. 2006).

\begin{tabular}{llcrr}
\hline \hline \multicolumn{1}{c}{ Species } & \multicolumn{1}{c}{$\delta^{13} \mathrm{C}$} & \multicolumn{1}{c}{$\delta^{15} \mathrm{~N}$} & \multicolumn{1}{c}{$\mathrm{C}: \mathrm{N}$} & $n$ \\
\hline Fin whale & $-18.2(0.5)^{*}$ & $12.1(1.1)$ & $3.68(0.35)$ & 21 \\
Humpback whale & $-17.8(0.3)^{*}$ & $12.9(0.7)$ & $3.49(0.45)$ & 4 \\
Sprat (Age 0) & $-19.2(0.5)^{* *}$ & $12.2(0.2)$ & $3.54(0.33)$ & 4 \\
Sprat (Age 1) & $-19.8(0.6)^{* *}$ & $12.3(0.5)$ & $4.02(0.51)$ & 20 \\
Sprat (Age 2 +) & $-20.5(0.7)^{* *}$ & $12.3(0.6)$ & $4.72(0.70)$ & 15 \\
Herring (Age 0) & $-18.2(0.1)$ & $13.3(0.5)$ & $3.30(0.07)$ & 5 \\
Herring (Age 2) & $-19.6(0.3)^{* *}$ & $12.8(0.6)$ & $3.79(0.25)$ & 9 \\
Herring (Age 4) & $-19.4(0.5)^{* *}$ & $11.5(0.4)$ & $3.68(0.31)$ & 5 \\
Meganyctiphanes norvegica $(100 \mathrm{~m})$ & $-21.3(0.2)$ & $7.9(0.1)$ & $3.59(0.21)$ & 4 \\
Meganyctiphanes norvegica $(1,000 \mathrm{~m})$ & $-20.6(1.1)$ & $7.2(0.4)$ & $3.60(0.07)$ & 5 \\
Nyctiphanes couchii $(100 \mathrm{~m})$ & $-21.9(0.5)$ & $5.7(0.5)$ & $3.83(0.06)$ & 4 \\
\hline
\end{tabular}

humpback whale skin is not currently possible and standard chemical lipid extraction procedures lead to unpredictable changes in $\delta^{15} \mathrm{~N}$ values (Ryan et al. 2012a, Lesage et al. 2010). Therefore $\delta^{13} \mathrm{C}$ values from lipid-extracted skin and $\delta^{15} \mathrm{~N}$ values analyzed from nonextracted aliquots of skin were used as end-members (consumers) in mixing models.

\section{Diet Modeling}

Diet solutions were estimated by mixing models via Bayesian inference using the SIAR package in the statistical programming environment, $\mathrm{R}$ (Parnell et al. 2008, R Development Core Team 2011). SIAR utilizes the generalized multivariate equivalent of the Beta distribution, Dirichlet, as a prior which treats each dietary source (prey) independently but necessitates a sum to unity (i.e., that diet proportions sum to 1). Models are fitted hierarchically using Markov chain Monte Carlo (MCMC) to produce parameter estimates based on both the data and the prior distribution. Probabilistic density estimates of proportionate dietary contributions of sources (prey) to end members (whale skin) are thus derived. The advantage of this approach over alternative mixing model techniques is the ability to include uncertainty that is unconstrained by the number of sources used (Phillips and Gregg 2003). SIAR was chosen over other Bayesian mixing models (e.g., MixSIR) as it includes a residual error term which is incorporated into diet solutions, thereby recognizing unknown sources of error in the observed data. Thus uncertainty in inter alia: trophic enrichment factors, sources, and end members are explicitly accounted for in the SIAR model (Parnell et al. 2010).

Using fish muscle and whole zooplankton as sources and whale skin as end members (prey), 500,000 iterations (thinned by 20 and with a burn-in discard of 10,000) were used to derive posterior distributions of source contributions. The diet-tissue discrimination factors used in our mixing models, for both fin and humpback whales $\left(1.28 \pm 0.38\right.$ for $\delta^{13} \mathrm{C}$ and $2.82 \pm 0.30$ for $\left.\delta^{15} \mathrm{~N}\right)$ were derived for lipid-extracted fin whale skin (Borrell et al. 2012). Lipid-extraction leads to small but unpredictable changes in $\delta^{15} \mathrm{~N}$ values $(0.1 \% \pm 1.2 \mathrm{SD})$ in fin and humpback whale skin (Ryan 
et al. 2012b). This discrepancy represents a caveat, albeit a very minor one, in our study. No such discrimination factors have been calculated for humpback whales, however, closely related cetacean taxa are known to exhibit similar values (Newsome et al. 2010, Caut et al. 2011). Whale species (fin and humpback whale) was used as a grouping factor to investigate resource preferences by species. Concentration independent models were appropriate in the present study (Phillips and Koch 2002), as model inputs comprised only animal tissues (as opposed to plant tissues) which are likely to exhibit similar elemental concentrations of carbon and nitrogen and are partitioned in a similar manner from food sources.

In SIAR mixing models, negative correlation can arise between posterior dietary proportions of sources as one source is traded off against another. In mixing model solutions as the abundance of one source increases, that of other sources necessarily decreases as their total relative abundance must equal 1 . Thus, negative correlation indicates poor ability for the model to differentiate these prey contributions to diet solutions. Strong correlations may arise due to the configuration of sources (prey) around the mixture (predator) in isotopic space, whereby sources located in the extremities relative to the mixture may result in high correlations. Pair-wise correlations were calculated to evaluate this covariance structure in posterior distributions, to ensure that the models unambiguously isolated individual source contributions (Parnell et al. 2010). Probability of model parameters (M) given the prior data $(D)$ is presented in order to investigate differences in diet source contributions, among prey and between fin and humpback whales. These probabilities (Pr) are derived by Bayesian inference whereby lower $\operatorname{Pr}(M \mid D)$ values imply lower support of the hypothesis.

\section{Results}

Sufficient evidence from the literature was determined to postulate some of the dietary sources for fin and humpback whales in the CS (Burfield 1913, Fairley 1981, Bentaleb et al. 2011, Whooley et al. 2011, Gregori et al. 2012). The following prey species were therefore used as sources in the mixing models: sprat, herring, $M$. norvegica, and N. couchii.

According to age-class, sprat exhibited markedly consistent $\delta^{15} \mathrm{~N}$ values, whereas those of herring were more variable (Fig. 2, Table 1). After lipid normalization, older fish were less enriched in ${ }^{13} \mathrm{C}$, although age 4 herring were more enriched than age 2 herring. M. norvegica exhibited higher $\delta^{19} \mathrm{~N}$ and $\delta^{13} \mathrm{C}$ values compared to $N$. couchii (Fig. 2, Table 1). After tissue treatments, $\mathrm{C}: \mathrm{N}$ ratios were similar among all source and consumer tissues, justifying the use of concentration independent models (Table 1). The $\delta^{15} \mathrm{~N}$ and $\delta^{13} \mathrm{C}$ values of skin biopsies for fin and humpback whales overlapped considerably, although there was greater variability in fin whale values (Fig. 2, Table 1). A small sample of humpback whales limited our ability to quantify the degree of this overlap.

\section{Mixing Model Diagnostics}

Pair-wise correlations revealed a strong negative relationship between the contribution of $M$. norvegica and $N$. couchii $(-0.71)$ to fin whale diet. Of 18 pair-wise correlations for sources, three were greater than -0.30 for fin whales, but none were for humpback whales. Correlations of -0.44 were found between age 4 herring and both 


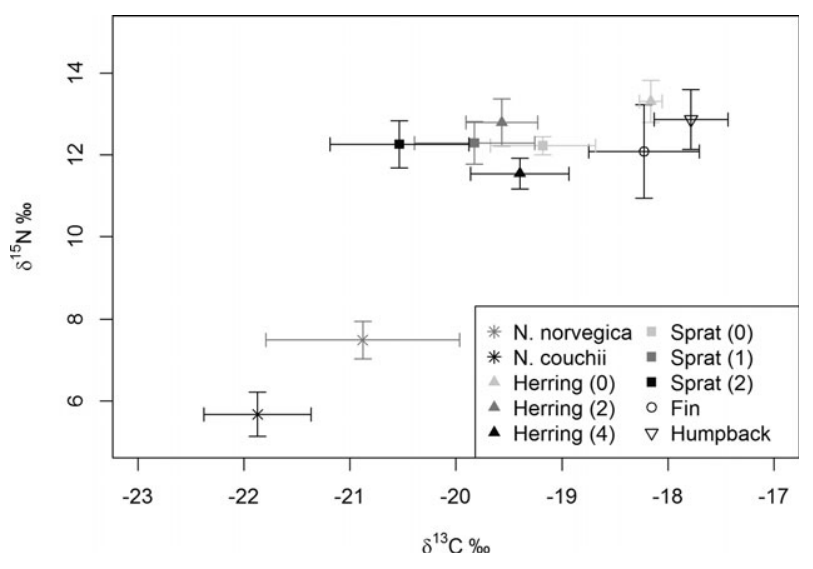

Figure 2. A biplot showing the actual consumer isotopic values and those of putative prey (sources) which have not been corrected-for using tissue-diet discrimination factors. Fishes are plotted by year class in parentheses where age was estimated from total length. This shows the large difference in $\delta^{15} \mathrm{~N}$ between fishes and krill, and similar isotopic values for both carbon and nitrogen in fin and humpback whales.

age 0 herring and $M$. norvegica. Age 0 sprat and age 0 herring showed a similar negative correlation $(-0.43)$ for fin whales only. Mixing models were rerun where sprat and herring age classes were pooled but correlations between source posterior distributions were greater $(<-0.50)$, providing justification for the stratification of fish isotopic data by age.

\section{Mixing Model Solutions}

In Bayesian inference, given data $(D)$ and a model $(M)$ the probability from the posterior distribution is presented as $\operatorname{Pr}(D \mid M)$. Assuming that the model includes all major diet sources, both fin and humpback whale diets included large proportions of fish. Krill comprised a greater proportion of the diet of fin whales than in humpback whales $(\operatorname{Pr}(D \mid M)=0.979)$. For fin whales, krill species were collectively the most dominant (maximum a posteriori probability estimate, low-high $95 \%$ credibility intervals) diet component $(0.46,0.22-0.59)$. Both fin and humpback whales were found to have a preference for age 0 sprat $(0.22,0.00-0.37$ and $0.30,0.01-$ 0.38 , respectively) and herring $(0.17,0.01-0.35$ and $0.22,0.02-0.36$, respectively) (Fig. 4). The probability that krill comprised a greater proportion than the next most abundant component (age 0 sprat) was 0.996 (Fig. 3, 4). While there was a high probability that age 0 sprat were more abundant in fin whale diet solution than either age $1(0.696)$ or age $2(0.786)$, the probability that sprat was greater than herring when posterior age class distributions were pooled was very low, $\operatorname{Pr}(D$ $M)=0.318$ (Fig. 3, 4). Krill exhibited a wide range in $\delta^{13} \mathrm{C}$ which is consistent with a high degree of spatio-temporal variability within the sample (Fig. 2). Despite this, however, the mixing model solutions show unambiguous isotopic separation between fish and krill, leading to reduced uncertainty when partitioning diet sources (Fig. 3). 


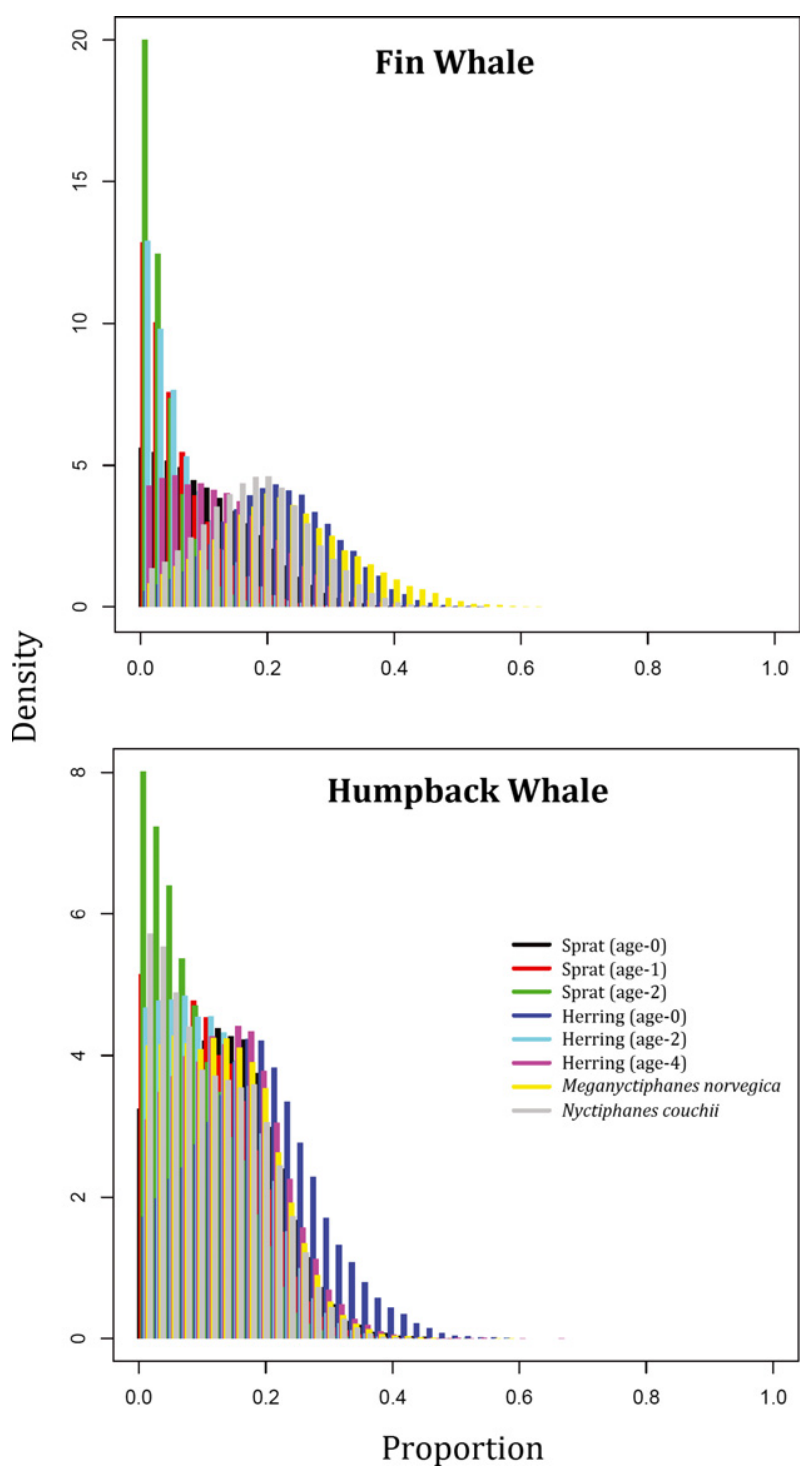

Figure 3. Probability density histograms showing the distribution of posterior parameters from the SIAR model, based on 500,000 iterations. The model estimated that fin whale (top) diet is predominated by krill, whereas humpback whales (bottom) consumed relatively more fish species. Age 0 herring followed by age 0 sprat were the most important fish components in the diets of both whale species.

\section{Discussion}

A prior assessment of likely diet components of fin and humpback whales in the CS was made, based on the best available evidence from the literature and field observations. This guided the selection of sources for the isotope mixing model. A caveat 

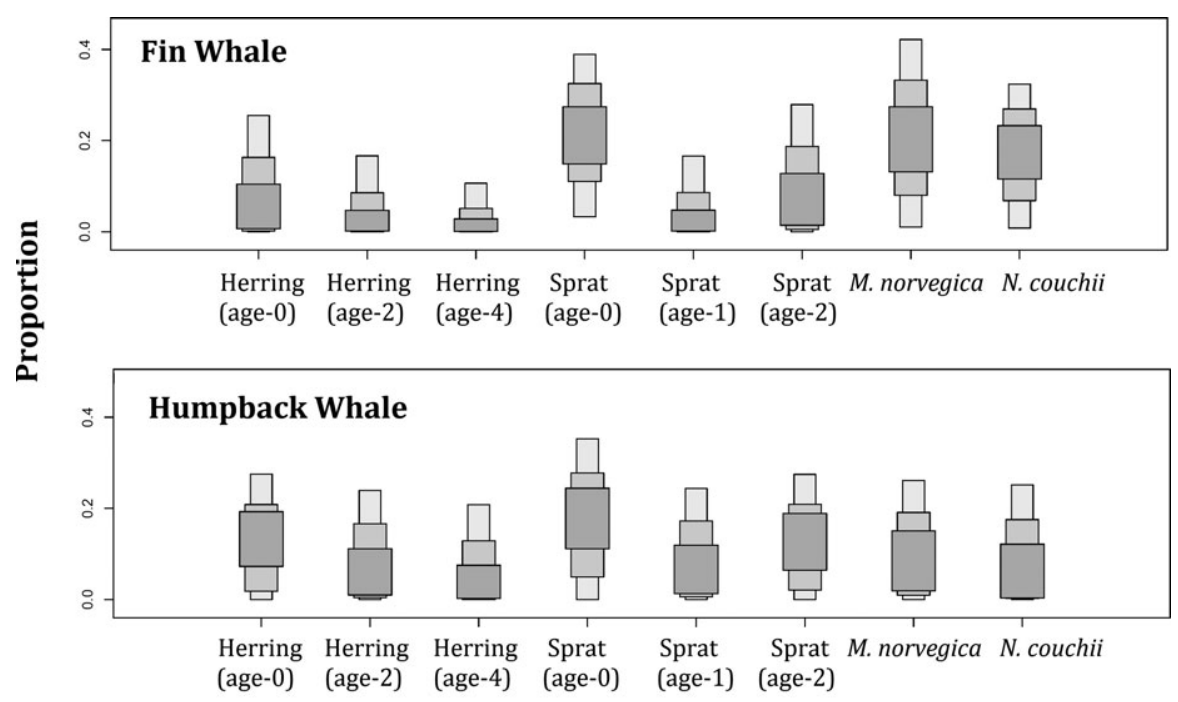

\section{Sources}

Figure 4. Box plots showing the differential proportionate contribution of sources in modeled diet solutions for fin (above) and humpback (below). Credibility intervals are presented as dark (50\%), intermediate (75\%), and light (95\%) boxes. For fishes, the age according to length is given in parenthesis.

of this approach was that sources used in the mixing models were unlikely to be an exhaustive representation of the species diversity in the diet of fin and humpback whales which may feed on other fishes, e.g., anchovy (Engraulis encrasicolus), pilchard (Sardina pilchardus), mackerel or blue whiting (Micromesistius poutassou), or indeed other species of zooplankton, e.g., Calanus spp. or Thysanoessa spp. However, there was no evidence from the literature, or from field observations indicating that these species are preyed upon by fin and humpback whales in the CS or contiguous waters. While a sufficient sample size was obtained for fin whales $(n=21)$, it should be noted that results for humpback whales are based on a small sample $(n=4)$ and should therefore be interpreted with caution. A potential source of bias in our results is the differential tissue turnover rate between krill and fish muscle. This source of temporal variability may have resulted in an under-representation of krill proportions in the mixing model solutions, given that the entire isotopic range of krill may not have been sampled. However, previous studies have found low spatio-temporal variability both $\delta^{15} \mathrm{~N}$ and $\delta^{13} \mathrm{C}$ values of $M$. norvegica in the NEA $\left(38^{\circ}-45^{\circ} \mathrm{N}, 12^{\circ}-\right.$ $13^{\circ} \mathrm{W}$ ) whereby seasonal differences in isotope values were not significantly different (Bentaleb et al. 2011).

Mixing model solutions confirmed that fin and humpback whales are both planktivorous and piscivorous in the CS. While krill (M. norvegica and $N$. couchii) make up a large proportion of their diets, especially for fin whales, both whale species were also found to have a preference for age 0 sprat and herring respectively. Proportions of both age 0 sprat and age 0 herring were not easily differentiated by the mixing models. It is likely that this is ecologically relevant rather than a model artifact, given the propensity for mixed species shoals of age 0 sprat and herring in the CS, collectively 
known as "whitebait." Similarly, sprat and herring fisheries are unlikely to be selective in catching these shoals. The importance of age 0 sprat and herring in the diet of both fin and humpback whales should be considered in the management of CS fisheries. The weak negative correlation between age 0 herring an $M$. norvegica in fin whale diet solutions may also be an ecological effect. Fin whales may feed either on herring on the shelf or on $M$. norvegica where they are most abundant at the shelf break, situated $c a .200 \mathrm{~km}$ from where the biopsies were collected. It is unlikely that they feed on both species over small temporal scales given the distances between the core habitats of these prey species.

Krill species including both $M$. norvegica and $N$. couchii comprised about half of the diet in fin whales. Humpback whales by comparison consumed significantly lower proportions of krill species, indicating a more piscivorous diet. This result is consistent with recent findings based on stable isotope analysis of baleen, which suggest that humpback whales occupy a higher trophic level than fin whales in the CS (Ryan et al. 2012b). Given that krill comprised one of the smallest dietary components in humpback whales, exploitation of shared resources between fin and humpbacks whales in the CS might only be short-lived. The proportions of each krill species that are being consumed remain to be resolved. M. norvegica and N. couchii occur chiefly in offshore and shelf waters respectively, therefore discerning which of these species comprise the preferred prey for fin and humpback whales should be a research priority. This may shed light on feeding strategies when the whales are foraging offshore, beyond the current reach of researchers. Fatty acid analysis of blubber biopsies may provide more conclusive insights on this issue (Borobia et al. 1995, Grahl-Nielsen 2009).

Sympatric positive density-dependent foraging by fin and humpback whales has been found at high latitudes in both the eastern and western North Atlantic, owing to the patchiness of prey and suitable foraging conditions (Piatt and Methven 1990, Skern-Mauritzen et al. 2011). Given that these species have evolved to be obligate batch-feeders, prey fields of suitable magnitude and density are critical for optimal foraging leading to threshold foraging behavior (Piatt and Methven 1990, Goldbogen et al. 2011). Facilitation or perhaps a degree of cooperation among these species, as well as seabirds and other marine predators, may be necessary to both locate and contain prey (Rudd et al. 2011). In light of this, the trade-off between positive density-dependent foraging and resource partitioning likely culminates in complex community structure among rorquals which merits further research if management measures are to be implemented using an ecosystem-based approach. Furthermore, spawning herring have been shown to exhibit structurally stable schools that emerge only after threshold population sizes are reached (Vabø and Skaret 2008). If feeding whales exploit this synchronous behavioral trait in herring, then optimal foraging might not be met for reduced densities of herring which could occur at a local scale due to disruption caused by trawling, or at the population scale due to over-fishing.

Over-exploitation of benthic fishes such as gadoids, has resulted in a reduced trophic system (at a rate of -0.02 to $-0.04 \mathrm{TL} / \mathrm{yr}$ ) in the CS from which pelagic fishes such as clupeids may benefit by increased biomass (relative to other species in the ecosystem) in spite of fishing intensity (Pauly et al. 1998, Pinnegar et al. 2002, Minto and Worm 2012). Fisheries may benefit from this lower trophic community structure whereby higher fishery yields are achieved (Pinnegar et al. 2002). Paradoxically, those cetaceans that preferentially feed at lower trophic levels, e.g., baleen whales feeding on krill and clupeids, may benefit from this fisheries-induced ecosystem modification. Whether relative abundance of rorqual whales in the CS (namely fin, humpback, and 
minke $[B$. acutorostrata $]$ whales) has increased in recent years is not currently possible to discern due to a lack of sightings data prior to the 1990s. In light of a declining trophic system and recovery of both fish and whale populations from over-exploitation in the region, it is incumbent on fisheries management to adopt an ecosystem approach. This will be necessary to effectively conserve top predators including fin and humpback whales, while maintaining secure ecosystem functioning on which sustainable fisheries rely.

The CS herring fishery is unusual from a fisheries management perspective in that commercial exploitation began after routine stock assessment was already in place (Pinnegar et al. 2002). CS herring spawn at the southern-most limit of the species range in the NEA and are therefore particularly vulnerable to changes brought about by climatic change. The two stocks exhibit "spawning diversity," believed to be a survival strategy, where autumn and winter spawning components are subject to different survival and recruitment driven by environmental factors and fishery mortality (Harma et al. 2012). The relative proportion of autumn-spawning to winter-spawning herring is currently at its lowest since 1959, a trend strongly influenced by the Atlantic Multi-decadal Oscillation (Harma et al. 2012). Such a seasonal shift may have significant implications for rorqual whales, which being capital breeders, are seasonally constrained in their foraging habits: generally feeding at high latitude in summer and breeding in low latitudes during winter (Jonsgard 1966, Baker et al. 1990). A retraction towards winter-dominated spawning may lead to mismatch between spawning (and hence coastal aggregations of herring) and the foraging window for whales, given their reproductive requirements to breed at lower latitudes during the winter.

\section{ACKNOWLEDGMENTS}

The Irish Research Council, Global Biodiversity Information Facility, and Ireland Newfoundland Partnership funded this research. Thanks to those who helped in the field: Pádraig Whooley, Collin Barnes, Fien de Raedemaeker, Allesandro Pierini, Nick Massett, Andrew Malcolm, Ann Trimble, Mick Sheeran, Joanne O'Brien, Deirdre Slevin, Paddy Roche, Brian Duffy, and Martin Colfer. Thanks to Commodore Mark Mellett and Commanding Officer of L. É. Orla Caoimhín Mac Unfraidh, Irish Naval Service for assistance. Thanks to Brian Boyle and Poppy for help with the Soxlhet apparatus. We gratefully acknowledge Niall Fallon for assisting with fish ageing. Thanks to Dave Wall, the scientists and crew of RV Celtic Explorer for help with collecting fish and plankton samples. Andrew Jackson is gratefully acknowledged for providing open-source help files for SIAR mixing models. The authors would like to acknowledge the use of Maptool (www.seaturtle.org) for the graphics in Figure 1. We are grateful to Loïc Michel and another anonymous reviewer who helped in improving the manuscript. The

co-authors declare no conflict of interest. Biopsy samples were collected under permit from the National Parks and Wildlife Service, Ireland (License Numbers C76/2008, C82/2009, and C130/2010).

\section{Literature Cited}

Baker, C. S., S. R. Palumbi, R. H. Lambertsen, M. T. Weinrich, J. Calambokidis and S. J. O'Brien. 1990. Influence of seasonal migration on geographic distribution of mitochondrial DNA haplotypes in humpback whales. Nature 344:238-240. 
Becker, B. H., and S. R. Beissinger. 2006. Centennial decline in the trophic level of an endangered seabird after fisheries decline. Conservation Biology 20:470-479.

Bentaleb, I., C. Martin, M. Vrac, et al. 2011. Foraging ecology of Mediterranean fin whales in a changing environment elucidated by satellite tracking and baleen plate stable isotopes. Marine Ecology Progress Series 438:285-302.

Borobia, M., P. J. Gearing, Y. Simard, J. N. Gearing and P. Beland. 1995. Blubber fatty acids of finback and humpback whales from the Gulf of St. Lawrence. Marine Biology 122:341-353.

Bowen, W. D., and D. Lidgard. 2012. Marine mammal culling programs: Review of effects on predator and prey populations. Mammal Review. doi:10.1111/j.1365-2907.2012. 00217.x.

Brodie, P. F., D. D. Sameoto and R. W. Sheldon. 1978. Population densities of euphausiids off Nova Scotia as indicated by net samples, whale stomach contents, and sonar. Limnology and Oceanography 23:1264-1267.

Burfield, S. T. 1913. Report of the committee appointed to investigate the biological problems incidental to the Belmullet whaling station. Report of the Eighty-second Meeting of the British Association for the, Advancement of Science. p 186.

Caut, S., S. Laran, E. Garcia-Hartmann and K. Das. 2011. Stable isotopes of captive cetaceans (killer whales and bottlenose dolphins). Journal of Experimental Biology 214:538-545.

Chivers, L. S., M. G. Lundy, K. Colhoun, S. F. Newton and N. Reid. 2012. Diet of blacklegged kittiwakes (Rissa tridactyla) feeding chicks at two Irish colonies highlights the importance of clupeids. Bird Study 59:363-367.

DeNiro, M. J., and S. Epstein. 1978. Influence of diet on the distribution of carbon isotopes in animals. Geochimica et Cosmochimica Acta 42:495-506.

DeNiro, M. J., and S. Epstein. 1981. Influence of diet on the distribution of nitrogen isotopes in animals. Geochimica et Cosmochimica Acta 45:341-351.

Enever, R., A. Revill and A. Grant. 2007. Discarding in the English Channel, Western approaches, Celtic and Irish seas (ICES subarea VII). Fisheries Research 86:143-152.

Fairley, J. S. 1981. Irish whales and whaling. Blackstaff Press, Belfast, Ireland.

Focken, U., and K. Becker. 1998. Metabolic fractionation of stable carbon isotopes: Implications of different proximate compositions for studies of the aquatic food webs using $\delta^{13} \mathrm{C}$ data. Oecologia 115:337-343.

Gearing, P. J., J. N. Gearing, J. T. Maughan and C. A. Oviatt. 1991. Isotopic distribution of carbon from sewage sludge and eutrophication in the sediments and food web of estuarine ecosystems. Environmental Science \& Technology 25:295-301.

Gerber, L. R., L. Morissette, K. Kaschner, et al. 2009. Should whales be culled to increase fishery yield. Science 323:880-881.

Goericke, R., and B. Fry. 1994. Variations of marine plankton $\delta^{13} \mathrm{C}$ with latitude, temperature, and dissolved $\mathrm{CO}_{2}$ in the world ocean. Global Biogeochem Cycles 8:85-90.

Goldbogen, J. A., J. Calambokidis, E. Oleson, J. Potvin, N. D. Pyenson, G. Schorr and R. E. Shadwick. 2011. Mechanics, hydrodynamics and energetics of blue whale lunge feeding: Efficiency dependence on krill density. Journal of Experimental Biology 214:131-146.

Grahl-Nielsen, O. 2009. Exploration of the foraging ecology of marine mammals by way of the fatty acid composition of their blubber. Marine Mammal Science 25:239-242.

Greene, C. H., and A. J. Pershing. 2004. Climate and the conservation biology of North Atlantic right whales: The right whale at the wrong time? Frontiers in Ecology and the Environment 2:29-34.

Gregori, M., F. J. Aznar, E. Abollo, Á. Roura, Á. González and S. Pascual. 2012. Nyctiphanes couchii as intermediate host for the acanthocephalan Bolbosoma balaenae in temperate waters of the NE Atlantic. Diseases of Aquatic Organisms 99:37.

Griffiths, D. 1980. Foraging costs and relative prey size. American Naturalist:743-752.

Harma, C., D. Brophy, C. Minto and M. Clarke. 2012. The rise and fall of autumn-spawning herring (Clupea harengus L.) in the Celtic Sea between 1959 and 2009: Temporal trends in spawning component diversity. Fisheries Research 121:31-42. 
Hicks, B. D., D. J. St. Aubin, J. R. Geraci and W. R. Brown. 1985. Epidermal growth in the bottlenose dolphin, Tursiops truncatus. Journal of Investigative Dermatology 85:60-63.

Hobson, K. A. 1999. Tracing origins and migration of wildlife using stable isotopes: A review. Oecologia 120:314-326.

Hofmann, M., D. A. Wolf-Gladrow, T. Takahashi, S. C. Sutherland, K. D. Six and E. MaierReimer. 2000. Stable carbon isotope distribution of particulate organic matter in the ocean: A model study. Marine Chemistry 72:131-150.

Hooker, S. K., and L. R. Gerber. 2004. Marine reserves as a tool for ecosystem-based management: The potential importance of megafauna. BioScience 54:27-39.

Jacob, U., K. Mintenbeck, T. Brey, R. Knust and K. Beyer. 2005. Stable isotope food web studies: A case for standardized sample treatment. Marine Ecology Progress Series 287:251-253.

Jennings, S., J. K. Pinnegar, N. V. C. Polunin, et al. 2002. Linking size-based and trophic analyses of benthic community structure. Marine Ecology Progress Series 226:77-85.

Jennings, S., and K. J. Warr. 2003. Environmental correlates of large-scale spatial variation in the $\delta^{15} \mathrm{~N}$ of marine animals. Marine Biology 142:1131-1140.

Jonsgard, A. 1966. The distribution of Balaenopteridae in the North Atlantic Ocean. Pages 114-123 in K. S. Norris, ed. Whales, dolphins and porpoises. University of California Press, Berkeley, CA.

Kiljunen, M., J. Grey, T. Sinisalo, C. Harrod, H. Immonen and R. I. Jones. 2006. A revised model for lipid normalizing ${ }^{13} \mathrm{C}$ values from aquatic organisms, with implications for isotope mixing models. Journal of Applied Ecology 43:1213-1222.

Le Boeuf, B. J. 1994. Pages 237-252Elephant seals: Population ecology, behavior, and physiology. University of California Press, Berkeley, CA.

Lesage, V., Y. Morin, È. Rioux, C. Pomerleau, S. H. Ferguson and É. Pelletier. 2010. Stable isotopes and trace elements as indicators of diet and habitat use in cetaceans: Predicting errors related to preservation, lipid extraction, and lipid normalization. Marine Ecology Progress Series 419:249-265.

Lindley, J. A. 1982. Population dynamics and production of euphausiids. Marine Biology 66:37-46.

Lynch, D., J. Wilson and M. Clarke. 2011. Growth rate fluctuations of herring in the Celtic Sea: A history of life on the edge. ICES Conference Meeting Document 2011/D:07. Available at http://www.ices.dk. 16 pp.

Martínez del Rio, C., N. Wolf, S. A. Carleton and L. Z. Gannes. 2009. Isotopic ecology ten years after a call for more laboratory experiments. Biological Reviews 84:91-111.

McConnaughey, T., and C. P. McRoy. 1979. Food-web structure and the fractionation of carbon isotopes in the Bering Sea. Marine Biology 53:257-262.

Minto, C., and B. Worm. 2012. Interactions between small pelagic fish and young cod across the North Atlantic. Ecology 93:2139-2154.

Moore, J. W., and B. X. Semmens. 2008. Incorporating uncertainty and prior information into stable isotope mixing models. Ecology Letters 11:470-480.

Newsome, S. D., M. T. Clementz and P. L. Koch. 2010. Using stable isotope biogeochemistry to study marine mammal ecology. Marine Mammal Science 26:509-572.

Österblom, H., O. Olsson, T. Blenckner and R. W. Furness. 2008. Junk-food in marine ecosystems. Oikos 117:967-977.

Overman, N. C., and D. L. Parrish. 2001. Stable isotope composition of walleye: ${ }^{15} \mathrm{~N}$ accumulation with age and area-specific differences in $\delta^{1 \frac{3}{3}} \mathrm{C}$. Canadian Journal of Fisheries and Aquatic Sciences 58:1253-1260.

Parnell, A., R. Inger, S. Bearhop and A. L. Jackson. 2008. SIAR: stable isotope analysis in R. Available at http://cran.r-project.org/web/packages/siar/index.html.

Parnell, A., R. Inger, S. Bearhop and A. L. Jackson. 2010. Source partitioning using stable isotopes: Coping with too much variation. PLoS One 5:e9672.

Pauly, D., V. Christensen, J. Dalsgaard, R. Froese and F. Torres Jr. 1998. Fishing down marine food webs. Science 279:860-863. 
Pauly, D., V. Christensen, S. Guénette, et al. 2002. Towards sustainability in world fisheries. Nature 418:689-695.

Peterson, B. J., and B. Fry. 1987. Stable isotopes in ecosystem studies. Annual Review in Ecology and Systematics 18:293-320.

Phillips, D. L., and J. W. Gregg. 2001. Uncertainty in source partitioning using stable isotopes. Oecologia 127:171-179.

Phillips, D. L., and J. W. Gregg. 2003. Source partitioning using stable isotopes: Coping with too many sources. Oecologia 136:261-269.

Phillips, D. L., and P. L. Koch. 2002. Incorporating concentration dependence in stable isotope mixing models. Oecologia 130:114-125.

Phillips, D. L., S. D. Newsome and J. W. Gregg. 2005. Combining sources in stable isotope mixing models: Alternative methods. Oecologia 144:520-527.

Piatt, J. F., D. A. Methven, A. E. Burger, R. L. McLagan, V. C. Mercer and E. Creelman. 1989. Baleen whales and their prey in a coastal environment. Canadian Journal of Zoology 67:1523-1530.

Piatt, J. F., and D. A. Methven. 1990. Threshold foraging behavior of baleen whales. Marine Ecology Progress Series 84:205-210.

Pierce, G. J., M. B. Santos and S. Cervino. 2007. Assessing sources of variation underlying estimates of cetacean diet composition: A simulation study on analysis of harbour porpoise diet in Scottish (UK) waters. Journal of the Marine Biological Association of the United Kingdom 87:213-221.

Pikitch, E. K., C. Santora, E. A. Babcock, et al. 2004. Ecosystem-based fishery management. Science 305:346-347.

Pinnegar, J. K., S. Jennings, C. M. O’Brien and N. V. C. Polunin. 2002. Long-term changes in the trophic level of the Celtic Sea fish community and fish market price distribution. Journal of Applied Ecology 39:377-390.

R Development Core Team. 2011. R: A language and environment for statistical computing. Austria, Vienna.

Rucklidge, G. J., G. Milne, B. A. McGaw, E. Milne and S. P. Robins. 1992. Turnover rates of different collagen types measured by isotope ratio mass spectrometry. Biochima et Biophysica Acta 1156:57-61.

Rudd, A. B., A. J. Titmus, B. Gisborne and J. P. Heath. 2011. Association of marbled murrelets Brachyramphus marmoratus with foraging gray whales Eschrichtius robustus on the southwest coast of Vancouver Island, British Columbia. Marine Ornithology 39:261-266.

Ryan, C., B. McHugh, I. O'Connor and S. Berrow. 2012a. Lipid content in blubber biopsies is not representative of blubber in situ for fin whales (Balaenoptera physalus). Marine Mammal Science 29: doi:10.1111/j.1748-7692.2012.00578.x.

Ryan, C., B. McHugh, C. N. Trueman, C. Harrod, S. D. Berrow and I. O’Connor. $2012 b$. Accounting for the effects of lipids in stable isotope $\left(\delta^{13} \mathrm{C}\right.$ and $\left.\delta^{15} \mathrm{~N}\right)$ analysis of skin and blubber of balaenopterid whales. Rapid Communications in Mass Spectrometry 26:2745-2754.

Ryan, C., B. McHugh, C. N. Trueman, et al. 2013. Stable isotope analysis of baleen reveals resource partitioning among sympatric rorquals and population structure in fin whales. Marine Ecology Progress Series. doi:10.3354/meps10231.

Saunders, R., C. O’Donnell and A. Campbell, et al. 2010. Celtic Sea Herring Acoustic Survey Cruise Report 2010. Marine Institute Report. Available from Marine Institute, Rinville, Oranmore, Co. Galway, Ireland. 63 pp.

Skern-Mauritzen, M., E. Johannesen, A. Bjørge and N. Øien. 2011. Baleen whale distributions and prey associations in the Barents Sea. Marine Ecology Progress Series 426:289-301.

Søreide, J. E., T. Tamelander, H. Hop, K. A. Hobson and I. Johansen. 2006. Sample preparation effects on stable $\mathrm{C}$ and $\mathrm{N}$ isotope values: A comparison of methods in Arctic marine food web studies. Marine Ecology Progress Series 328:17-28. 
Sotiropoulos, M. A., W. M. Tonn and L. I. Wassenaar. 2004. Effects of lipid extraction on stable carbon and nitrogen isotope analyses of fish tissues: Potential consequences for food web studies. Ecology of Freshwater Fish 13:155-160.

St. Aubin, D. J., T. G. Smith and J. R. Geraci. 1990. Seasonal epidermal molt in beluga whales, Delphinapterus leucas. Canadian Journal of Zoology 68:359-367.

Stearns, S. C. 1976. Life-history tactics: A review of the ideas. Quarterly Review of Biology 51:3-47.

Sweeting, C. J., N. V. C. Polunin and S. Jennings. 2006. Effects of chemical lipid extraction and arithmetic lipid correction on stable isotope ratios of fish tissues. Rapid Communications in Mass Spectrometry 20:595-601.

Tagliabue, A., and L. Bopp. 2008. Towards understanding global variability in ocean carbon13. Global Biogeochemical Cycles 22:13.

Todd, S., P. Ostrom, J. Lien and J. Abrajano. 1997. Use of biopsy samples of humpback whale (Megaptera novaeangliae) skin for stable isotope $\left(\delta^{13} \mathrm{C}\right)$ determination. Journal of Northwest Atlantic Fishery Science 22:71-76.

Trenkel, V., J. K. Pinnegar, W. A. Dawson, M. H. Du Buit and A. N. Tidd. 2005. Spatial and temporal structure of predator-prey relationships in the Celtic Sea fish community. Marine Ecology Progress Series 299:257-268.

Trites, A. W., V. Christensen and D. Pauly. 2006. Effects of fisheries on ecosystems: Just another top predator? Pages 11-27 in I. L. Boyd, S. Wanless and C. J. Camphuysen, eds. Atlantic top predators in marine ecosystems. Cambridge University Press, Cambridge, U.K.

Vabø, R., and G. Skaret. 2008. Emerging school structures and collective dynamics in spawning herring: A simulation study. Ecological Modelling 214:125-140.

Verity, P. G., V. Smetacek and T. J. Smayda. 2002. Status, trends and the future of the marine pelagic ecosystem. Environmental Conservation 29:207-237.

Ward, E. J., B. X. Semmens, D. L. Phillips, J. W. Moore and N. Bouwes. 2011. A quantitative approach to combine sources in stable isotope mixing models. Ecosphere 2.

Whooley, P., S. D. Berrow and C. Barnes. 2011. Photo-identification of fin whales (Balaenoptera physalus L.) off the south coast of Ireland. Marine Biodiversity Records e4.

Witteveen, B. H., G. A. J. Worthy, R. J. Foy and K. M. Wynne. 2011. Modeling the diet of humpback whales: An approach using stable carbon and nitrogen isotopes in a Bayesian mixing model. Marine Mammal Science 28:e233-e250.

Received: 17 September 2012 Accepted: 22 February 2013 